\title{
Does platelet-rich plasma have a favorable effect in the early stages of steroid-associated femoral head osteonecrosis in a rabbit model?
}

\author{
Trombositten zengin plazmanın tavşan modelinde steroide bağlı \\ femur başı osteonekrozunun erken evrelerinde olumlu etkisi var mıdır?
}

\author{
Mustafa Karakaplan, MD, ${ }^{1}$ Deniz Gülabi, MD, ${ }^{2}$ Haldun Topgül, MD, ${ }^{3}$ Nurzat Elmalı, MD ${ }^{4}$ \\ 'Department of Orthopedics and Traumatology, Medical Faculty of İnönü University, Malatya, Turkey \\ ${ }^{2}$ Department of Orthopedics and Traumatology, Dr. Lütfi Kırdar Kartal Training and Research Hospital, İstanbul, Turkey \\ ${ }^{3}$ Department of Orthopedics and Traumatology, Harput State Hospital, Elazığ, Turkey \\ ${ }^{4}$ Department of Orthopedics and Traumatology, Medical Faculty of Bezmialem Foundation University, İstanbul, Turkey
}

\begin{abstract}
Objectives: This study aims to investigate the effect of platelet-rich plasma (PRP) on femoral head osteonecrosis and compare it with bone marrow injection and core decompression.

Materials and methods: A total of 30 healthy, adult, male New Zealand white rabbits (mean weight $2.25 \pm 0.15 \mathrm{~kg}$; range 2.0 to $2.5 \mathrm{~kg}$ ) were used in the study. To create experimental osteonecrosis in all rabbits, $40 \mathrm{mg} / \mathrm{kg}$ methylprednisolone acetate was applied intramuscularly. Rabbits were randomly allocated into three groups with 10 rabbits in each: drilling group, PRP group, and bone marrow group. The non-drilled hips of the drilling group were identified as the control group.

Results: Rate of necrotic bone was lower in the PRP group compared to other groups. Highest rate of necrotic bone was detected in the control group. New bone formation rate was higher in the PRP group compared to other groups. Lowest new bone formation rate was determined in the control group. Inflammatory reaction rate was higher in the PRP group compared to other groups.
\end{abstract}

Conclusion: Platelet-rich plasma injection may play a positive role in the treatment of steroid-associated osteonecrosis in a rabbit model.

Keywords: Bone marrow; core decompression; osteonecrosis; platelet-rich plasma.

Osteonecrosis of the femoral head affects patients aged 30 to 60 years, and is one of the main reasons for total hip arthroplasty. Several risk factors including cortisone use have been defined, but the pathogenesis
$\ddot{O Z z}$

Amaç: $\mathrm{Bu}$ çalışmada, femur başı osteonekrozunda Trombositten zengin plazma (TZP)'nın etkisi araştırıldı ve kemik iliği enjeksiyonu ve kor dekompresyon ile karşılaştırıldı.

Gereç ve yöntemler: Çalışmada 30 sağlıklı, erişkin, erkek Yeni Zelanda beyaz tavşanı (ort. ağırlık 2,25 $\pm 0,15 \mathrm{~kg}$; dağılım 2,0-2,5 kg) kullanıldı. Tüm tavşanlarda deneysel osteonekroz yaratmak için $40 \mathrm{mg} / \mathrm{kg}$ metilprednizolon asetat kas içine uygulandı. Tavşanlar her grupta 10 tavşan olacak şekilde rastgele üç gruba ayrıldı: Oyma grubu, TZP grubu, kemik iliği grubu. Oyma grubunun oyulmayan kalçaları kontrol grubu olarak belirlendi.

Bulgular: Trombositten zengin plazma grubunda nekrotik kemik oranı diğer gruplara kıyasla daha düşük idi. En yüksek nekrotik kemik oranı kontrol grubunda saptandı. Yeni kemik oluşumu oranı TZP grubunda diğer gruplara kıyasla daha yüksek idi. En düşük yeni kemik oluşumu oranı kontrol grubunda saptand1. İnflamatuvar reaksiyon oranı TZP grubunda diğer gruplara kıyasla daha fazla idi.

Sonuç: Trombositten zengin plazma enjeksiyonu tavşan modelinde steroide bağlı osteonekroz tedavisinde olumlu rol oynayabilir.

Anahtar sözcükler: Kemik iliği; kor dekompresyon; osteonekroz; trombositten zengin plazma.

of the disease has not yet been elucidated. ${ }^{[1]}$ The disease has a progressive course and the end stage results in hip joint destruction and arthritis, thus leading to restricted movement and a decreased quality of life.

- Received: December 30, 2016 Accepted: March 28, 2017

- Correspondence: Deniz Gülabi, MD. Kartal Dr. Lütfi Kırdar Eğitim ve Araştırma Hastanesi Ortopedi ve Travmatoloji Kliniği, 34890 Kartal, İstanbul, Turkey. Tel: +90 216 - 4413900 / 1441 e-mail: dgulabi@yahoo.com 
Surgical and non-surgical modalities have been described for the treatment of this progressive and destructive disease. In femoral head preserving surgery, osteotomies of various kinds have been used for many years. Treatment with joint replacement is controversial because of the age of the patients involved and the number of complications observed in this disease. Early diagnosis allows for treatment of the disease at an earlier stage, thereby potentially improving the outcome. In the early stages, conservative treatments involve non-weightbearing using crutches, while antihypertensive, lipidlowering, fibrinolytic, and vasoactive agents have also been proposed. Core decompression has been suggested as a treatment modality very early in the course of the disease, with the reduction of the elevated intraosseous pressure by holes drilled into the diseased femoral head, thereby promoting vascular ingrowth. ${ }^{[2]}$

Recent studies have shown that osteonecrosis of the femoral head (ONFH) is highly related to a decrease or alterations of marrow mesenchymal stem cells or other progenitor cells in the proximal femur ${ }^{[3]}$ and it has been gradually accepted that ONFH originates from the cellular level. Burwell ${ }^{[4]}$ showed that primitive osteogenic cells in bone marrow (BM) are responsible for much of the biological efficacy of cancellous bone grafts. Friedenstein et al. ${ }^{[5]}$ showed that new bone was formed by proliferative fibroblast-like marrow cells which persisted in vitro after hematopoietic cells had died and that the number of cells able to proliferate rapidly could be assayed by counting the number of fibroblastic colony-forming units in BM. Due to the cells and proteins in the BM, BM injection was proposed for the treatment of osteonecrosis in 1990 and good results have been reported. ${ }^{[6]}$

Platelet-rich plasma (PRP) is defined as a sample of autologous blood with concentrations of platelets above baseline values. Platelets play an instrumental role in the normal healing response via the local secretion of growth factors and recruitment of reparative cells. ${ }^{[7]}$ Its use in orthopedics began early in this decade as PRP was used with bone grafts to augment spinal fusion and fracture healing. ${ }^{[8]}$

In this study, we aimed to investigate the effect of PRP on femoral head osteonecrosis and compare it with $\mathrm{BM}$ injection and core decompression.

\section{MATERIALS AND METHODS}

The present study was approved by the Animal Experiment Committee of İnönü University. The study was conducted in accordance with the principles of the Declaration of Helsinki. The principles of laboratory animal care were followed, all procedures were conducted in accordance with the guidelines established by the National Institutes of Health and every effort was made to minimize the suffering of the animals. A total of 30 healthy, adult, male New Zealand white rabbits (mean weight $2.25 \pm 0.15 \mathrm{~kg}$; range 2.0 to $2.5 \mathrm{~kg}$ ) were used. All rabbits were housed in standard cages with food and water ad libitum under a natural day/night cycle. Rabbits were randomly allocated into three groups with 10 rabbits in each: drilling group, PRP group, and BM group. The non-drilled hips of the drilling group formed the control group.

In an experimental study by Motomura et al., ${ }^{[9]}$ rabbits were injected once intramuscularly with $40 \mathrm{mg} / \mathrm{kg}$ of methylprednisolone acetate (MPSL). Four weeks after the MPSL injection, the proximal and distal parts of both the femora and humeri were histopathologically examined for the presence of osteonecrosis and the incidence of osteonecrosis was $96 \%$. In our study, at the first stage, $40 \mathrm{mg} / \mathrm{kg}$ MPSL was applied intramuscularly to create experimental osteonecrosis in all the rabbits, as described in the study by Motomura et al..$^{[9]}$ The rabbits were placed in spacious cages to allow free ambulation and they were checked daily to monitor welfare and manner of locomotion. ${ }^{[10]}$ They had free access to water and food at all times.

\section{Preparation of platelet-rich plasma}

Under anesthesia, a $15 \mathrm{~mL}$ blood sample was taken from the ear vein of the rabbits that were to undergo surgery. To prevent clotting, sodium citrate was added at the rate of $1 / 10$. The samples were placed in the centrifuge unit of an Arthrex $\mathrm{ACP}^{\circledR}$ Double Syringe system (Arthrex Inc., Naples, Florida, USA) and were centrifuged for 5 minutes at $1500 \mathrm{rpm}$. When separation of the plasma and red blood cells was seen, a second centrifuge process was applied at the same rates. Then, a structure of three layers was obtained of the upper layer of platelet-poor plasma, the middle layer of PRP and the lower layer of red blood cells. With the double syringe system, the upper and lower layers were removed, leaving the PRP section for use.

\section{Preparation of concentrated bone marrow}

Under anesthesia, $20 \mathrm{~mL}$ blood was taken from the posterior iliac wing with a $16 \mathrm{G}$ BM biopsy needle. Sodium citrate was added to the blood sample at the rate of $1 / 10$. The samples were then centrifuged at $3000 \mathrm{rpm}$ for 15 minutes. The upper section of plasma was removed leaving the lower section of concentrate prepared for use. ${ }^{[11]}$ 


\section{Surgical procedure}

At the end of four weeks, anesthesia of $40 \mathrm{mg} / \mathrm{kg}$ ketamine (Ketalar [Beseri İlaç, Luleburgaz, Kırklareli, Turkey]) and $5 \mathrm{mg} / \mathrm{kg}$ xylazine were applied intramuscularly and the left hip area of each rabbit was shaved and wiped with betadine solution. A cutaneous and subcutaneous incision was made with a lancet, then, under C-arm fluoroscopy guidance over the bone notch which could be palpated from the lateral, the femoral neck and femoral head were drilled with a $2.7 \mathrm{~mm}$ drill. Anteroposterior and lateral images were taken to ensure that the drilling under fluoroscopy guidance was within the femoral neck and the drilling was continued as far as the cartilage below the femoral head (Figures 1 and 2). In drilling group, only drilling was applied. A plug of bone wax was applied to the hole in the lateral cortex after drilling to prevent the outside leakage of the administered PRP or BM in PRP and BM groups. Subcutaneous tissues were then closed with $4 / 0$ Vicryl sutures and the skin with 4/0 Prolene. Finally, a dressing was applied to the wound and the animals were left to recover.

\section{Follow-up}

Following the surgical treatment, the animals were monitored in the Experimental Animal Breeding and Research Centre of İnönü University. The rabbits were placed in spacious cages to allow free movement and were checked daily to monitor their well-being and manner of locomotion. After a period of six weeks after surgery, all the animals were sacrificed under anesthesia of $40 \mathrm{mg} / \mathrm{kg}$ ketamine (Ketalar) and $5 \mathrm{mg} / \mathrm{kg}$ xylazine applied intramuscularly with an intracardiac administration of potassium

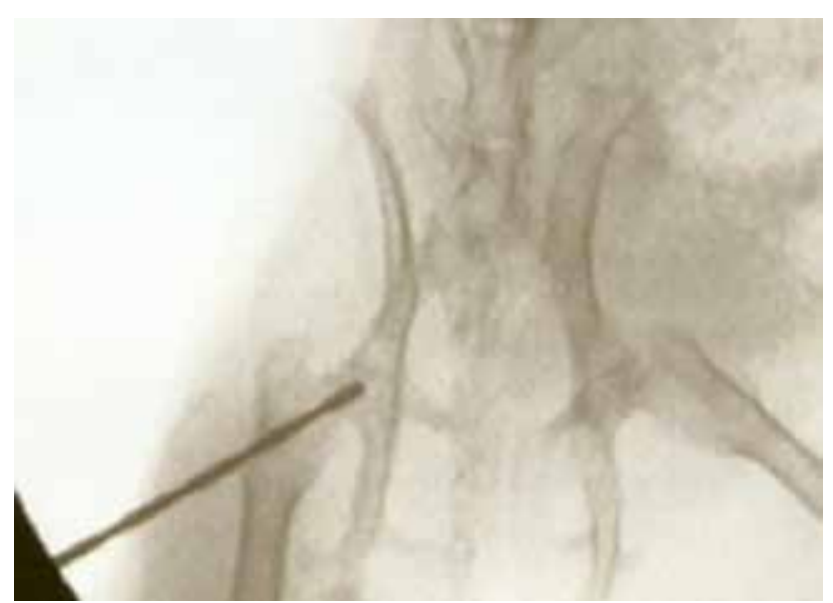

Figure 1. Drilling of rabbit left femoral head and neck under fluoroscopy guidance. Anteroposterior fluoroscopy image. chloride. Then, both femurs of the drilling group were removed, while left femurs were removed in PRP and BM groups.

The removed bones were separated into groups, fixed in $10 \%$ formaldehyde and placed in separate dishes. The bones were left for one week in the solution, then, the head and neck sections were cut from the intertrochanteric region with a motorized saw and again placed in 10\% formaldehyde solution. After a two-day waiting period, the materials were left in 10\% nitric acid for the decalcification process. When the bones softened after two days and became suitable for cutting, all the samples were cut into two equal pieces with a lancet and routine tissue processing was applied. Sections of 5-7 microns in thickness were cut from the prepared paraffin blocks, stained with hematoxylin and eosin and then examined with a light microscope.

The parameters of interest were semiquantitatively graded on a scale as percentage ratios. A pathologist used an examination technique that was a modification of Kataoka et al.'s. ${ }^{[12]}$ In the histopathological examination, percentage ratios were obtained for each femoral head based on the evaluation by the pathologist of necrosis, new bone structure, inflammatory reaction and areas of fibrosis. The characteristic features of osteonecrosis are the loss of hematopoietic, fat and bone cells together with osteocytes. Characteristically, when empty osteocyte lacunae and osteoblast surface activity are not seen, the bone is seen as an acellular structure. Generally, necrotic bone is defined histologically as weakly

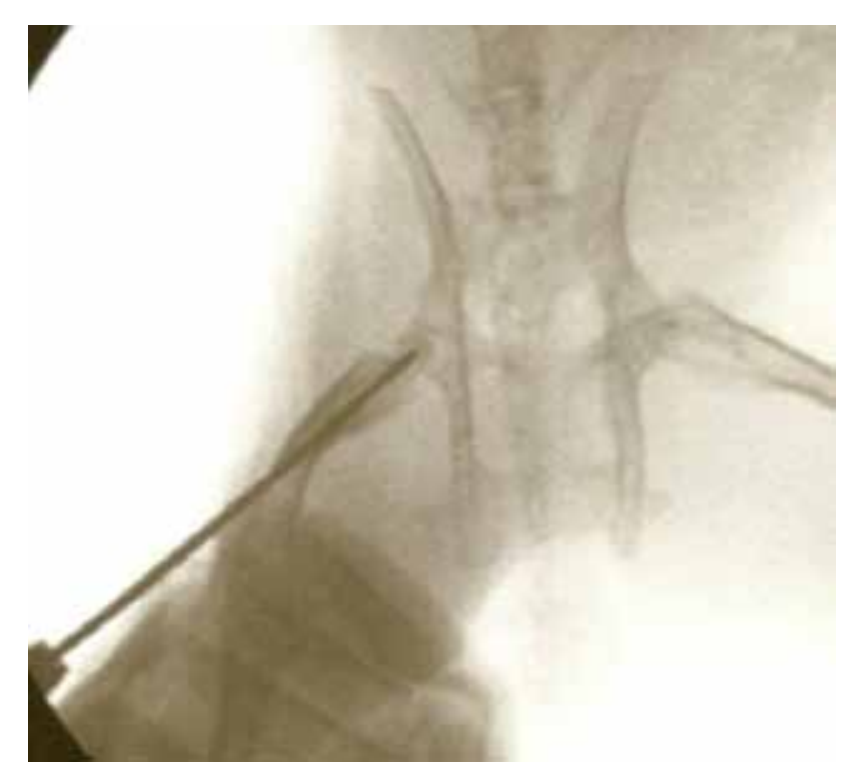

Figure 2. Drilling of rabbit left femoral head and neck under fluoroscopy guidance. Lateral fluoroscopy image. 
TABLE I

Results of pathological evaluation

\begin{tabular}{|c|c|c|c|}
\hline & Mean $\pm S D$ & Min-Max & Range \\
\hline \multicolumn{4}{|l|}{ Necrosis (\%) } \\
\hline \multicolumn{4}{|l|}{ Group } \\
\hline Control & $13.75 \pm 11.877$ & $0-30$ & 30 \\
\hline Bone marrow & $15.00 \pm 7.906$ & $5-30$ & 25 \\
\hline Platelet-rich plasma & $10.56 \pm 3.909$ & $5-20$ & 15 \\
\hline Core decompression & $11.25 \pm 9.543$ & $0-30$ & 30 \\
\hline \multicolumn{4}{|l|}{ New bone formation (\%) } \\
\hline \multicolumn{4}{|l|}{ Group } \\
\hline Control & $5.00 \pm 14.142$ & $0-40$ & 40 \\
\hline Bone marrow & $9.44 \pm 9.825$ & $0-30$ & 30 \\
\hline Platelet-rich plasma & $27.78 \pm 14.814$ & $10-50$ & 40 \\
\hline Core decompression & $13.13 \pm 5.939$ & $5-20$ & 15 \\
\hline \multicolumn{4}{|l|}{ Inflammatory reaction (\%) } \\
\hline \multicolumn{4}{|l|}{ Group } \\
\hline Control & $0.00 \pm 0.000$ & $0-0$ & 0 \\
\hline Bone marrow & $2.22 \pm 4.410$ & $0-10$ & 10 \\
\hline Platelet-rich plasma & $15.00 \pm 18.371$ & $0-50$ & 50 \\
\hline Core decompression & $10.63 \pm 8.634$ & $0-20$ & 20 \\
\hline \multicolumn{4}{|l|}{ Fibrosis (\%) } \\
\hline \multicolumn{4}{|l|}{ Group } \\
\hline Control & $.00 \pm .000$ & $0-0$ & 0 \\
\hline Bone marrow & $4.44 \pm 10.138$ & $0-30$ & 30 \\
\hline Platelet-rich plasma & $17.22 \pm 23.064$ & $0-60$ & 60 \\
\hline Core decompression & $2.50 \pm 3.780$ & $0-10$ & 10 \\
\hline
\end{tabular}

stained cortical and trabecular bone. The pathologist making the assessments was blinded to the treatment groups of the rabbits.

\section{Statistical analysis}

The statistical analysis of the findings obtained in the study was performed using SPSS for Windows version 13.0 software (SPSS Inc., Chicago, IL, USA). Quantitative data were stated as mean, standard deviation, median, minimum and maximum values and qualitative data as number and percentage. Comparison of the groups in respect of the quantitative data of histological variables (necrosis, new bone formation, inflammatory reaction, fibrosis) was performed using Kruskal-Wallis analysis of variance and paired comparisons were performed with the Conover test. A value of $\mathrm{p}<0.05$ was accepted as statistically significant (Table I).

\section{RESULTS}

During the six-week follow-up period, a total of four rabbits died: one in the BM group, two in the drilling group and one in the PRP group. Thus the six-week study period was completed with a total of 26 rabbits.

As a result of the Kruskal-Wallis one-way analysis of variance (ANOVA) in respect of necrosis, a value of $\mathrm{p}=0.0071$ was determined $(\mathrm{p}<0.05)$; so, paired comparisons with the Conover test were applied to all the groups. The rate of necrotic bone was found to be lower in the PRP group than in the other groups. The highest rate of necrotic bone was determined to be in the control group.

As a result of the Kruskal-Wallis one-way ANOVA in respect of new bone formation, a value of $p=0.0013$ was determined $(p<0.05)$. Paired comparisons were conducted for all groups with the Conover test. New bone formation was determined at a higher rate in the PRP group compared to all other groups. The lowest rate of new bone formation was determined in the control group (Table II).

As a result of the Kruskal-Wallis one-way ANOVA in respect of inflammatory reaction, a value of $p=0.0158$ was determined $(p<0.05)$. Paired 
TABLE II

Evaluation of differences between groups in respect of new bone formation

\begin{tabular}{lcccc}
\hline & Control & Bone marrow & Platelet-rich plasma & Core decompression \\
\hline Control & & $\sqrt{ }$ & $\sqrt{ }$ \\
Bone marrow & & $\sqrt{ }$ & \\
Platelet-rich plasma & $\sqrt{ }$ & & \\
Core decompression & $\sqrt{ }$ & & \\
$\mathrm{r}=\mathrm{p}<0.05$. & &
\end{tabular}

TABLE III

Evaluation of differences between groups in respect of inflammatory reaction

\begin{tabular}{|c|c|c|c|c|}
\hline & Control & Bone marrow & Platelet-rich plasma & Core decompression \\
\hline \multicolumn{5}{|l|}{ Control } \\
\hline Bone marrow & & & $\sqrt{ }$ & $\sqrt{ }$ \\
\hline Platelet-rich plasma & & $\sqrt{ }$ & & \\
\hline Core decompression & & $\sqrt{ }$ & & \\
\hline
\end{tabular}

comparisons were conducted for all groups with the Conover test. Inflammatory reaction was determined at a higher rate in the PRP group compared to all other groups. The lowest rate of inflammatory reaction was determined in the control group (Table III).

No statistically significant results were determined as a result of the Kruskal-Wallis one-way ANOVA in respect of fibrosis as a value of $\mathrm{p}=0.1059$ was found $(\mathrm{p}>0.05)$.

\section{DISCUSSION}

Osteonecrosis of the femoral head follows a progressive course leading to femoral head collapse and hip joint destruction. Although the optimal method to preserve the femoral head remains unclear, many surgical methods have been described with conflicting results because of the extent of the pathological process. Platelet-rich plasma has been used in maxillofacial and plastic surgery since the 1990s. ${ }^{[8]}$ Despite currently available minimal clinical evidence, the use of PRP has increased in orthopedic pathologies, especially in muscular and tendinous problems. Platelets play an instrumental role in the normal healing response via the local secretion of growth factors and recruitment of reparative cells. ${ }^{[7]}$ Many controlled clinical trials are under way, but clinical use should be approached cautiously until high-level clinical evidence supporting PRP efficacy is available. The present study has shown the possible potent efficiency of PRP in the early stages of experimental osteonecrosis of the femoral head in a rabbit model.
Histologically, osteonecrotic lesions demonstrate an accumulation of BM cell debris and bone trabeculae possess empty lacunae and osteonecrotic-changed osteocytes. In the present study, necrosis was very prominent in the control group, and very rare in the PRP group. Little reparative response was observed in the control group. However, in the rabbits administered with PRP injection, there was a reparative process, including aggregation of macrophages and fibrous tissue invasion, and a small rate of appositional bone formation (Figure 3). The current study suggests that cotreatment with PRP may have a potent efficiency in steroid-associated osteonecrosis (SAON). This can be considered due to vascular endothelial growth factor, transforming growth factor beta 1, epidermal growth factor, insulin-like growth factor, and plateletderived growth factor as described by Radke et al. ${ }^{[13]}$ The reparative processes, especially aerogenesis and osteogenesis, but also resorption of necrotic tissular debris, were reported to be evidently enhanced by the PRP treatment.

Since osteonecrosis may be a disease of mesenchymal cells or bone cells, the possibility has been raised that $\mathrm{BM}$ containing osteogenic precursors implanted into a necrotic lesion of the femoral head may be of benefit in the treatment of this condition. ${ }^{[8]}$ The hematopoietic stem cells in $\mathrm{BM}$ are pluripotent and also contain a stroma where the osteogenic precursor cells are found. The injected marrow stromal cells secrete angiogenic cytokines, resulting in increased angiogenesis and a subsequent improvement in osteogenesis. Song 


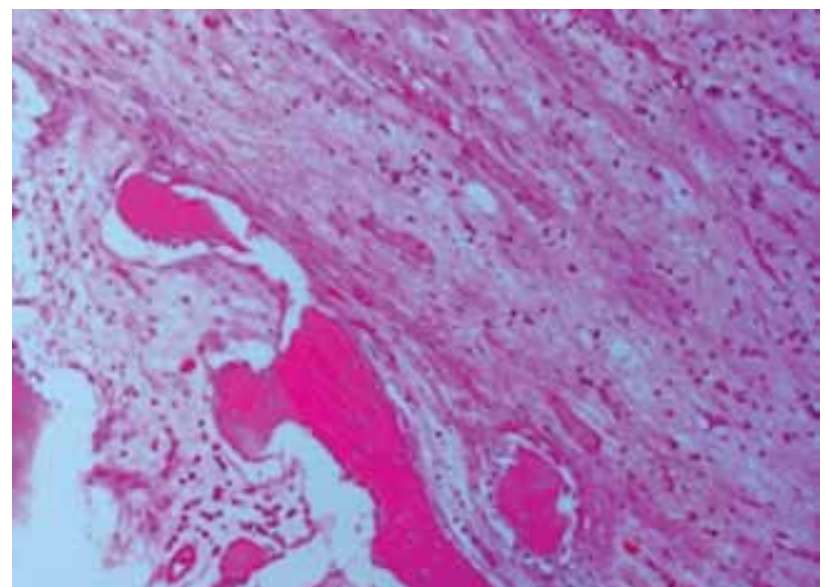

Figure 3. New bone formation within connective tissue of platelet-rich plasma group. Image of osteocytes located in lacunae and surrounding bone tissue and neovascularization in remodeling area $(\mathrm{H}-\mathrm{E} \times 200)$.

et al. ${ }^{[14]}$ determined that osteoblasts surrounding the trabecular bone and capillary were increased in a BM implantation group in an experimental study. A double blinded non-randomized study has indicated that delivering autologous $\mathrm{BM}$ mononuclear cells to patients with early stages of ONFH brought about a profound reduction in pain and joint symptoms and partly prevented the occurrence of fractural stages. ${ }^{[15]}$ However, BM injection is not effective in SAON because of the adverse effect of steroid on BM content. There is an increase in the amount of the fatty marrow in the intertrochanteric portion of SAON. A decrease of osteogenic stem cells has been seen in the $\mathrm{BM}$ of some of these patients. ${ }^{[16]} \mathrm{In}$ patients with osteonecrosis, abnormalities have been demonstrated in the $\mathrm{BM}$ of the iliac crest, following corticosteroid therapy, with a decrease in the stem-cell

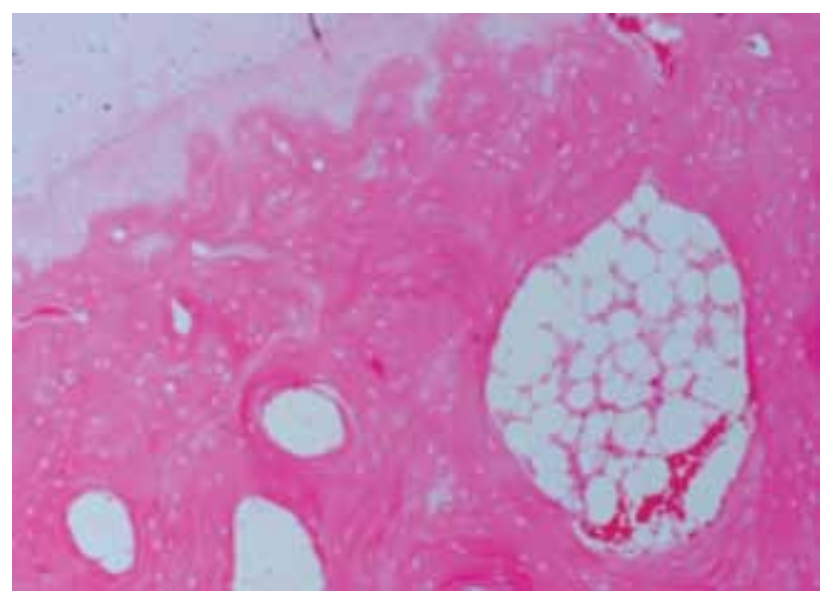

Figure 4. Image of bone tissue with empty lacunae in bone marrow group $(H-E \times 100)$. pool. ${ }^{[16]}$ In the current study, contrary to expectations, the expected positive effect was not observed in the osteonecrotic area in the group applied with BM. A lower inflammatory response, more necrosis and less osteogenic bone were seen (Figure 4). The negative effects of steroids on the BM in the iliac bone in the SAON process of the current study support previous reports in the literature.

Core decompression has been widely used for the treatment of early-stage osteonecrosis, and is intended to reduce intraosseous pressure in the femoral head, restore vascular flow, and improve pain. However, the results of core decompression have varied widely ranging from 29 to $84 \%$, and most results have been unsatisfactory in the reported literature. ${ }^{[17]}$ In the current study, as a result of the histopathological examination, the highest rate of necrosis, the lowest rate of inflammatory response and the lowest rate of new bone formation were determined in the drilling group (Figure 5). This was considered to be due to the weakening effect of the use of steroids in the repair process by decreasing the number of progenitor cells in the area. Thus, incomplete reconstructive repair and weakening of the trabecular bone within and next to the necrotic region may ultimately progress to subchondral collapse. ${ }^{[18]}$ One of the reasons for incomplete reconstructive repair after $\mathrm{SAON}$ is that the number of progenitor cells is decreased, especially in the proximal femur, which has been suggested in the recent literature by many authors. ${ }^{[5]}$

There are some limitations of the present study. First, noimmunohistochemical analysis was conducted of the growth factors in the PRP and BM solution and stem cells in the aspirates could not be calculated. Second, osteonecrosis of the femoral head could not

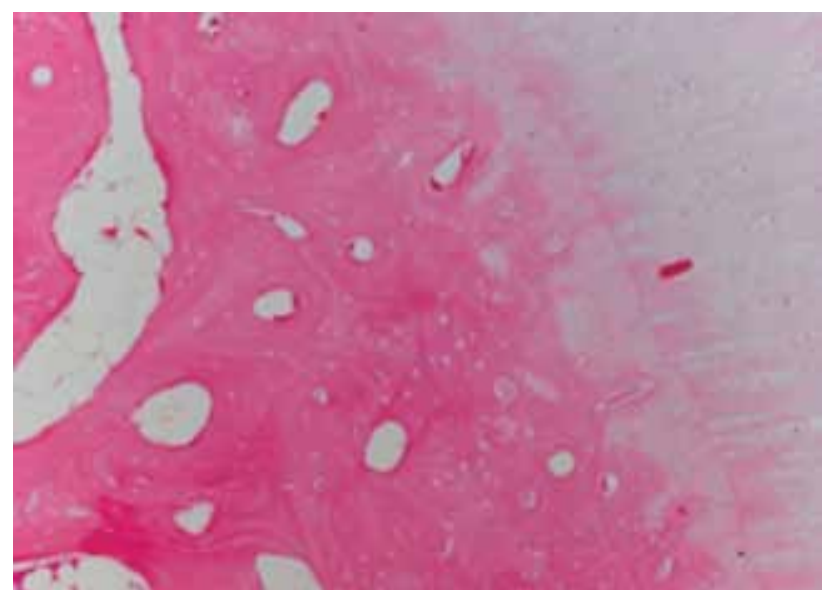

Figure 5. Image of organized bone structures with empty lacunae below cartilage of drilling group $(H-E \times 100)$. 
be verified by imaging techniques (i.e. magnetic resonance imaging [MRI] or roentgenogram), due to the high cost and MRI must be used in the early stages of osteonecrosis.

In conclusion, PRP injection may have a positive role in the treatment of SAON in a rabbit model. This novel treatment modality might have the potential to delay the need for total hip arthroplasty.

\section{Declaration of conflicting interests}

The authors declared no conflicts of interest with respect to the authorship and/or publication of this article.

\section{Funding}

The authors received no financial support for the research and/or authorship of this article.

\section{REFERENCES}

1. Atik OŞ. Overuse and abuse of cortisone. Eklem Hastalik Cerrahisi 2017;28:1.

2. Lieberman JR. Core decompression for osteonecrosis of the hip. Clin Orthop Relat Res 2004;418:29-33.

3. Hernigou P, Beaujean F, Lambotte JC. Decrease in the mesenchymal stem-cell pool in the proximal femur in corticosteroid-induced osteonecrosis. J Bone Joint Surg [Br] 1999;81:349-55.

4. Burwell RG. The function of bone marrow in the incorporation of a bone graft. Clin Orthop Relat Res 1985;200:125-41.

5. Friedenstein AJ, Petrakova KV, Kurolesova AI, Frolova GP. Heterotopic of bone marrow. Analysis of precursor cells for osteogenic and hematopoietic tissues. Transplantation 1968;6:230-47.

6. Hernigou P, Beaujean F. Treatment of osteonecrosis with autologous bone marrow grafting. Clin Orthop Relat Res 2002;405:14-23.

7. Eppley BL, Woodell JE, Higgins J. Platelet quantification and growth factor analysis from platelet-rich plasma: implications for wound healing. Plast Reconstr Surg 2004;114:1502-8.

8. Hall MP, Band PA, Meislin RJ, Jazrawi LM, Cardone DA.
Platelet-rich plasma: current concepts and application in sports medicine. J Am Acad Orthop Surg 2009;17:602-8.

9. Motomura G, Yamamoto T, Irisa T, Miyanishi K, Nishida K, Iwamoto Y. Dose effects of corticosteroids on the development of osteonecrosis in rabbits. J Rheumatol 2008;35:2395-9.

10. Beckmann R, Shaheen $H$, Kweider N, Ghassemi A, Fragoulis A, Hermanns-Sachweh B, et al. Enoxaparin prevents steroid-related avascular necrosis of the femoral head. ScientificWorldJournal 2014;2014:347813.

11. Xie XH, Wang XL, He YX, Liu Z, Sheng H, Zhang G, et al. Promotion of bone repair by implantation of cryopreserved bone marrow-derived mononuclear cells in a rabbit model of steroid-associated osteonecrosis. Arthritis Rheum 2012;64:1562-71.

12. Takaoka K, Yoshioka T, Hosoya T, Ono K, Takase T. The repair process in experimentally induced avascular necrosis of the femoral head in dogs. Arch Orthop Trauma Surg 1981;99:109-15.

13. Radke S, Battmann A, Jatzke S, Eulert J, Jakob F, Schütze N. Expression of the angiomatrix and angiogenic proteins CYR61, CTGF, and VEGF in osteonecrosis of the femoral head. J Orthop Res 2006;24:945-52.

14. Song H, Tao L, Wang F, Wang W, Wei Y, Shen W, et al. Effect of bone mesenchymal stem cells transplantation on the micro-environment of early osteonecrosis of the femoral head. Int J Clin Exp Pathol 2015;8:14528-34.

15. Gangji V, Hauzeur JP, Matos C, De Maertelaer V, Toungouz M, Lambermont M. Treatment of osteonecrosis of the femoral head with implantation of autologous bonemarrow cells. A pilot study. J Bone Joint Surg [Am] 2004;86:1153-60.

16. Hernigou P, Beaujean F. Abnormalities in the bone marrow of the iliac crest in patients who have osteonecrosis secondary to corticosteroid therapy or alcohol abuse. J Bone Joint Surg [Am] 1997;79:1047-53.

17. Wang CJ, Wang FS, Huang CC, Yang KD, Weng LH, Huang HY. Treatment for osteonecrosis of the femoral head: comparison of extracorporeal shock waves with core decompression and bone-grafting. J Bone Joint Surg [Am] 2005;87:2380-7.

18. Castro FP Jr, Barrack RL. Core decompression and conservative treatment for avascular necrosis of the femoral head: a metaanalysis. Am J Orthop (Belle Mead NJ) 2000;29:187-94. 